\title{
Urgency of Fiscal Policy to Overcome Welfare Gap in Indonesia
}

\author{
Abdul Aziz \\ Fiscal Policy Agency (FPA), Ministry of Finance of the Republic of Indonesia \\ kingabaz@gmail.com, aaziz@fiskal.depkeu.go.id
}

\begin{abstract}
This study aims to describe the condition of the welfare gap between residents and regions in Indonesia on a number of welfare indicators namely poverty depth index, poverty severity index, Gini Coefficient Index (GCI), and the Human Development Index (HDI). This study also aims to analyze the importance of fiscal policy, especially in the form of state expenditure allocations to minimize the gap. This study uses a quantitative descriptive analysis method that is by calculating some of the indicator data needed through the approach of average value, termun, standard devasi, and others. The result is a description of the welfare gap between people / regions in Indonesia and an overview of government policies that have been carried out. Whereas one of the recommendations is that the government should allocate state expenditures that are more effective, efficient, quality and pay attention to priority scale so that it can solve the welfare gap problem above.
\end{abstract}

Keywords: Welfare Gap, Welfare Indicator, Fiscal Policy, State Expenditure Allocation.

\section{Introduction}

One of the mandates in the Preamble of the 1945 Constitution of the Republic of Indonesia is that the state is obliged to protect the entire Indonesian nation and to promote the general welfare. Both countries' goals must be felt by all Indonesian people. The Government is determined to realize the noble goals in the Preamble of the Constitution including fiscal policy by allocating state expenditure to the State Budget (APBN) which aims to reduce the gap in the welfare of the Indonesian people and regions through various programs and activities financed by the APBN. The official data available turns out to still show a gap in welfare in the community. This gap can be seen from the conditions of poverty, community income disparities, and gaps in key areas of life such as education and health in the sample areas in Indonesia.

Poverty Conditions in Indonesia: Central Government Financial Report, the Ministry of Finance of Indonesia (LKPP MoF, 2017) explains that in the period 1999-September 2017 the poverty rate in Indonesia experienced a decline in both numbers and percentages except in 2006, September 2013 and March 2015. The increase in the number and percentage of poor people during that period triggered by the increase in prices of staple goods as a result of rising fuel prices. Still according to LKPP, MoF (2017) that the number of poor people in Indonesia in September 2017 reached 26.58 million people (10.12 percent) decreased compared to the conditions in March 2017 which amounted to 27.77 million (10.64 percent). There was a decrease in the number of poor people by 1.19 million people compared to March 2017. While compared to September of the previous year, the number of poor people decreased by 1.18 million people. Based on the area of residence, in the period March 2017-September 2017, the number of poor people in urban areas decreased by 401.28 thousand people while in rural areas decreased by 786.95 thousand people. The percentage of poverty in urban areas dropped from 7.72 percent to 7.26 percent. Meanwhile, in rural areas fell from 13.93 percent to 13.47 percent. This downward trend can be seen from graph 1 below. 


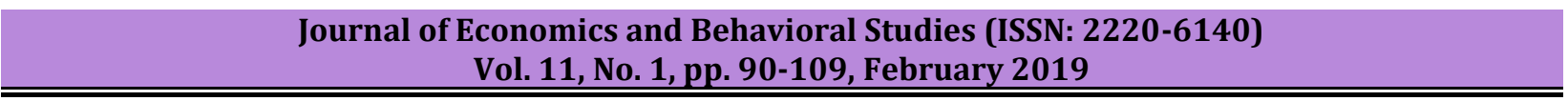

Graph 1: Development of the Amount and Percentage of Indonesia's Poor People

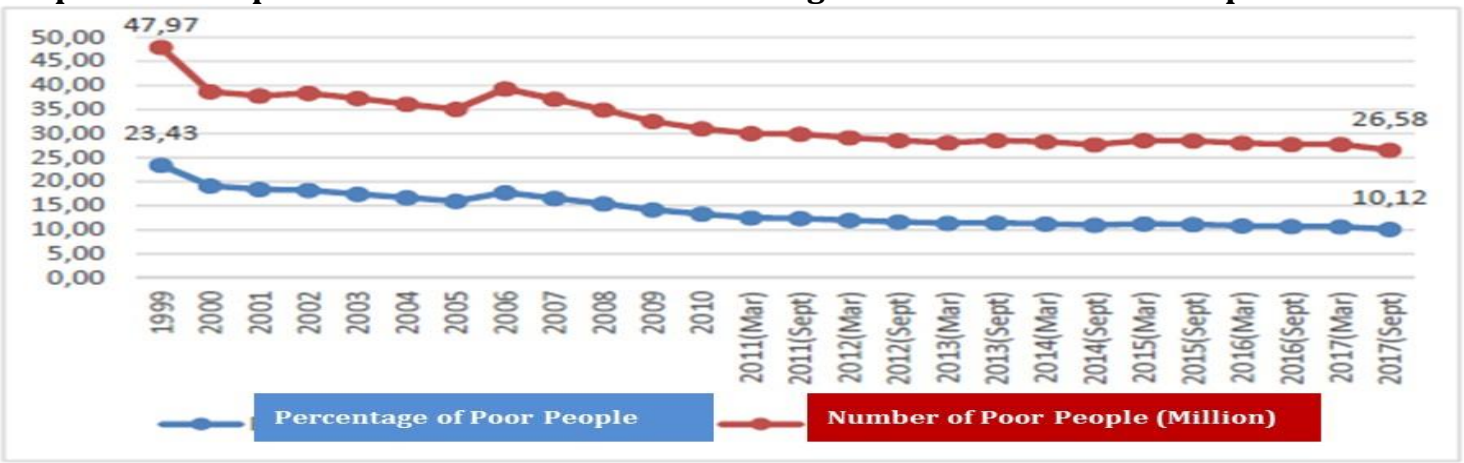

Source: BPS, (2017) in the LKPP 2017: May 2018

In Indonesia, the poverty level of a society is usually measured through various indices including the poverty severity index, the poverty depth index, and the Gini Coefficient Index.

Fiscal Policy Implementation in Indonesia: Actually, the government has done a lot of fiscal policies, especially in allocating state spending to reduce the gap in the welfare of its people. This can be seen from the classification of state expenditures based on Functions and Subfunctions as shown in table 1 below:

Table 1: State Budget Expenditures Based on Functions and Subfunctions Related to Efforts to Reduce Poverty and Improve People's Welfare

\begin{tabular}{|c|c|c|}
\hline $\begin{array}{l}\text { Function and Sub } \\
\text { Function Code }\end{array}$ & Function & Sub Function \\
\hline 06 & Housing and Public Facilities & \\
\hline 06.03 & & Supply of Drinking Water \\
\hline 06.04 & & Street Lighting \\
\hline 07 & Health & \\
\hline 07.01 & & Drugs and Health Supplies \\
\hline 07.02 & & Individual Health Services \\
\hline 07.03 & & Public Health Services \\
\hline 10 & Education & \\
\hline 10.01 & & Early childhood education programs \\
\hline 10.02 & & basic education \\
\hline 10.03 & & Middle education \\
\hline 10.04 & & Non-Formal and Informal Education \\
\hline 10.07 & & Aid Services to Education \\
\hline 11 & Social Protection & All Sub Functions \\
\hline 11.01SD 11.09 & & \\
\hline
\end{tabular}

Source: LKPP, MoF (2017)

The central government also allocates financial transfers to the regions and village funds (Funds Transfer to Regional Governments) at the district, city, and province level in the form of balance funds in each year of approximately $26 \%$ of budget state natural revenues. Fund transfers to the Regional Government consist of (a) Village Funds, (b) Balancing Funds consisting of General Allocation Funds (DAU), Special Allocation Funds (DAK), and Revenue Sharing Funds (DBH), (c) Regional Incentive Funds , (d) Yogyakarta Special Funds, and (e) Special Autonomy Funds. Village Funds are mandated by the Law on Villages and the first time distributed by the Central Government in 2015. 


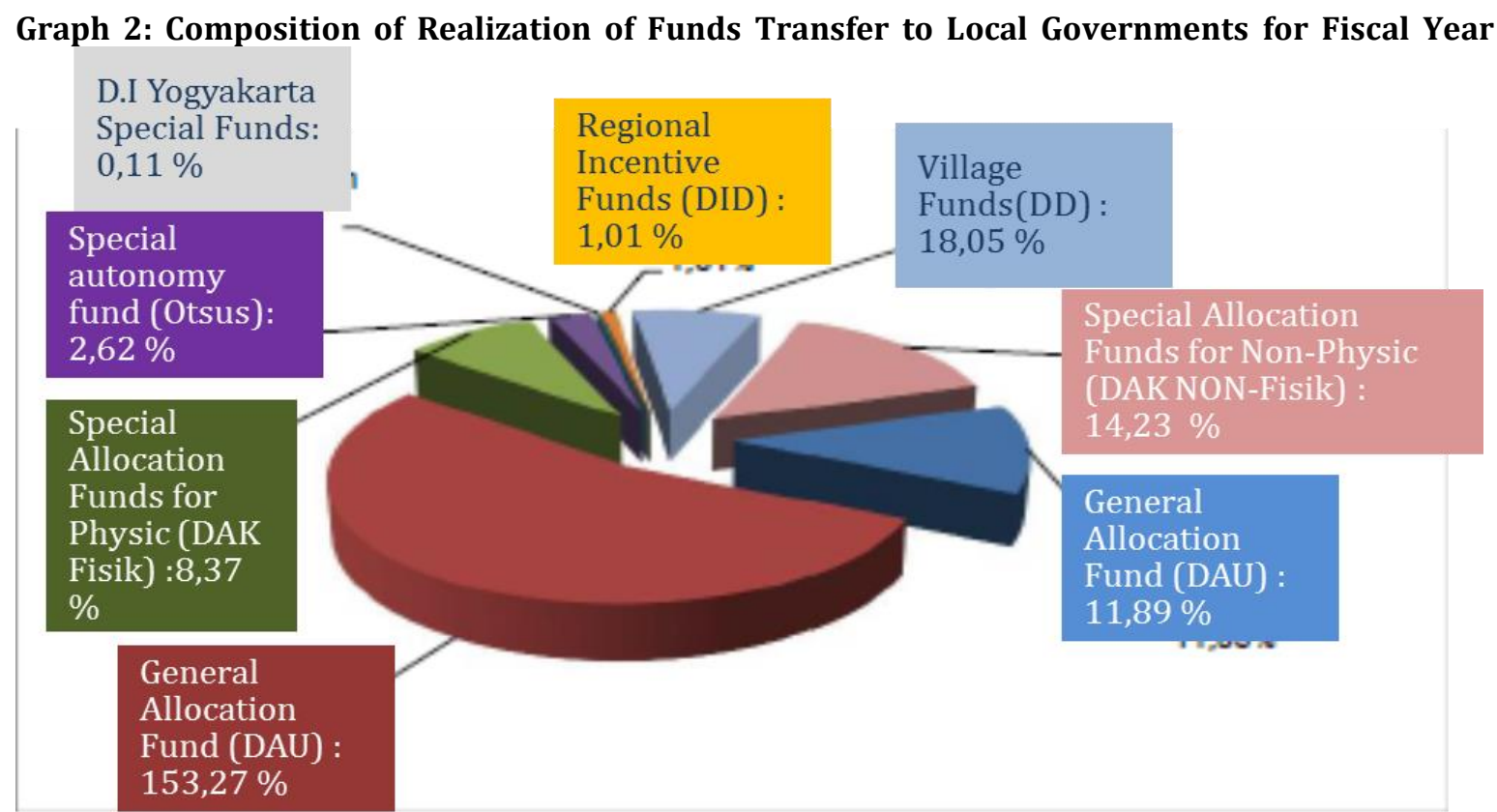

Source: LKPP, 2017 (May 2018), data edited

With the proportion of expenditure allocations as described above, this shows that in fact the Central Government and Regional Governments have programs and budgets which are aimed at improving public welfare. Based on the explanation above, this study has 2 objectives, namely:

- Describe several indicators of the gap in welfare between regions in Indonesia

- How the government implements fiscal policy (read: APBN) in order to support efforts to reduce the gap in welfare between regions in Indonesia.

\section{Research Methodology}

The Data Collection Method is carried out purposively, namely selecting a sample of poverty indicator data, welfare, and financial data of the central government expenditure and Fund Transfer data to the Regional Government at the provincial level. The selection of data at the provincial level has an important reason, that aside from being easy to compare between objects, observation is also easier to process and analyze because the amount of data is relatively small (only 33 data), unlike data at the district and city level which amounts to 542 pieces. The data analyzed are data on Poverty Depth Index, Poverty Severity Index, Gini Index, and Human Development Index. The data used in this study is secondary data derived from the official publication of the Indonesian Central Statistics Agency (BPS). In addition to these data, the author also uses State Budget data, especially on the side of state expenditure at the central government agencies and data on the balance funds received by the regional government from the central government.

This data is formally obtained from the Central Government Financial Report (LKPP, MoF)) that has been audited by the Indonesian Republic of Indonesia State Audit Agency (BPK). The year of observation used in this study is 2015-2016 and the maximum is up to 2017. The method of analysis used in this study is quantitative descriptive analysis by conveying a general description of the characteristics of the object under study without generalization. Data processing carried out in this paper is calculating data centre size measurements (such as: calculating averages), calculating the size of data dissemination (such as calculating range and standard deviation). The following are the formulas used in this article as instruments to explain the object of the indicators. 


\section{The Formula of Standard Deviation}

\begin{tabular}{|c|c|c|}
\hline$s=$ & $\frac{\sum_{i=1}^{n}\left(x_{i}-\bar{x}\right)^{2}}{n-1}$ & $\begin{array}{l}\text { Where: } \\
x i=\text { value of } x \text { for }-i \\
\bar{x}=\text { average } \\
n=\text { sample size }\end{array}$ \\
\hline
\end{tabular}

2. The Formula of Range

2. The Formula of Range
\begin{tabular}{|l|l|l|}
$R \quad X \max \quad-\quad X \min$ & $\begin{array}{l}\text { Where: } \\
\mathrm{R}=\text { Range/ Reach } \\
\text { Xmax = the largest data value } \\
\text { Xmin = the smallest data value. }\end{array}$ \\
\hline
\end{tabular}

3. The Formula of Mean

\begin{tabular}{|l|l|}
\hline $\bar{X}=\sum X / \mathrm{n}$ & $\begin{array}{l}\text { Where: } \\
X=\text { observation } \\
n=\text { Sample size }\end{array}$ \\
\hline
\end{tabular}

\section{Literature Review}

Welfare State: The welfare gap that occurs in a country demands the role of the state (read: the Government) to be involved in solving it. Such involvement can be carried out by issuing policies in the economic, political and other fields which aim to protect rights, improve welfare, and apply justice to all its people. Here are some things that are allowed by the formation of the welfare state as intended by Briggs and Orosz.

Briggs (1961) in Andersen (2012): "A welfare state is a state in which organized power is deliberately used (through politics and administration) in an effort to modify the play of the market forces in at least three directions: first, by guaranteeing individuals and families a minimum income irrespective of the market value of their work or their property; - second, by narrowing the extent of insecurity by enabling individuals and families to meet certain "social contingencies" (for example, sickness, old age and unemployment) which lead otherwise to individual and family crisis; and - third, by ensuring that all citizens without distinction of status or class are offered the best standards available in relation to a certain agreed range of social services."

Orosz (2017): "The concept of "The Welfare State", which appeared in the 1940s, is generally accepted as a wider definition of the role of the State in the field of social and economic policy. Most scholars of the subject, whether on the right or left politically, take it to mean a more positive and purposeful commitment by the government".

Fiscal Policy and Income Inequality: Income inequality is an obstacle to achieving successful development and high economic growth in a country. This condition must be resolved immediately, one of which is through the implementation of measured fiscal policies. Among the fiscal policies that can be done is by combining tax and transfers policies to the public simultaneously, fairly, and proportionally.

Bhatti, Naqvi, and Batool (2018): Income inequality is one of the critical barriers in most of the developing countries for growth and development. Income inequality remains a core issue in designing an effective fiscal policy. the inequalities in income are significantly higher than the inequalities in consumption. There are many factors which can affect income distribution. Many studies have been done in developed and developing countries to find out the effective policy measures to reduce the inequality in income distribution (In case of Pakistan). Furthermore, these three authors explained that a fine policy mix of tax and transfers can significantly improve the distribution (Leubker, 2011). Cubero and Hollar, (2010) prove in their study that the government can give any shape to the income distribution pattern by using tax and transfers. The nature of tax plays a very critical role in policy-making. Joumard et al. (2012) work on the same ground and find that a country having relatively small tax and transfer scheme attains the same redistribution effects as a country with higher tax rate and transfers if they rely on income tax which is progressive in nature. In evaluating the 
impact of fiscal policy, many researchers find a visible trade-off between equity and efficiency due to which many policymakers and politicians are seen reluctant in using fiscal policy for fair distribution of income.

Fiscal Policy for Pro-Poor Growth: Fiscal policy is also aimed at resolving the problem of poverty that continues to increase, but at the same time the fiscal policy implemented must also pay attention to the limits of the number of deficits and the amount of public debt allowed by existing laws and regulations.

Lustig (2018): Two key indicators of a government's (or society's) commitment to equalizing opportunities and reducing poverty and social exclusion are the share of total income devoted to social spending and how equalizing and pro-poor this spending is.3 Typically, redistributive social spending includes cash benefits4 and benefits in kinds such as spending on education and health. 5 As shown in Enami, Lustig, and Aranda (2018) and Enami (2018), the redistributive potential of a country does indeed depend on the size and composition of government spending and how it is financed, as well as the progressivity of all the taxes and government spending combined. While fiscal policy unambiguously reduces income inequality, this is not always true for poverty. In Ethiopia, Tanzania, Ghana, Nicaragua, Uganda, and Guatemala the extreme poverty headcount ratio is higher after taxes and transfers than before. In addition, to varying degrees, in all countries, a portion of the poor are net payers into the fiscal system and are thus impoverished by the fiscal system

Roy and Weeks (2004): Every government must maintain a sustainable fiscal policy. This includes a deficit that is manageable in the short term, and that the associated public debt it creates is serviceable. The economic function of government is not merely to maintain a stable macro environment; its primary responsibility to its citizens is to foster the general welfare. A deficit target should not be set that undermines a government's ability to achieve the latter.

\section{Poverty Indicators}

Poverty Depth Index: According to BPS (2017), Poverty Gap Index (Poverty Gap Index-P1), is a measure of the average gap in the expenditure of each poor population to the poverty line. The higher the index value, the further the average population expenditure from the poverty line. At each level, government decisions / policies that are very important are about the amount of the budget, what is the purpose and for what expenditure, and how to find funding to finance the budget.

Poverty Severity Index: According to BPS (2017), the Poverty Severity Index (P2) provides an overview of the spread of spending among the poor. This index means that the higher the index value, the higher the inequality of expenditure among the poor.

Gini Coefficient Index (GCI): Still according to BPS (2017), there are other measures that are usually used to determine the level of welfare gap between regions and communities, namely the Gini Coefficient Index (IKG). IKG is a number between 0 and 1, where 0 means "perfect equality" (i.e. everyone has equal income) and 1 means "perfect inequality" (where there is one person who makes all income, while others have zero income). Income distribution can vary greatly in the distribution of a country's wealth. The income from underground economic activities is not included in the calculation of this index.

Human Development Index (HDI): Besides the three indicators above, BPS (2017) also has other welfare indicator data, namely the Human Development Index (HDI), one of the measures that can show the success or failure of development in a region / country while showing the level of welfare, especially in education and health is to see the number of HDI in the region / country. The HDI was introduced by the United Nations Development Program (UNDP) in 1990 and is published regularly in the annual Human Development Report (HDR) report. BPS (2017), HDI explains how residents can access development results in obtaining income, health, education, and so on. The higher the HDI figure shows that the higher the level of population access to development results, especially in obtaining income, health and education. The HDI is formed by 3 (three) basic dimensions: long life and healthy life, knowledge, and a decent standard of living. The benefits of the HDI are: A). is an important indicator to measure success in efforts to build the quality of human life (community / population).

B). HDI can determine the ranking or level of development of a region / country. 


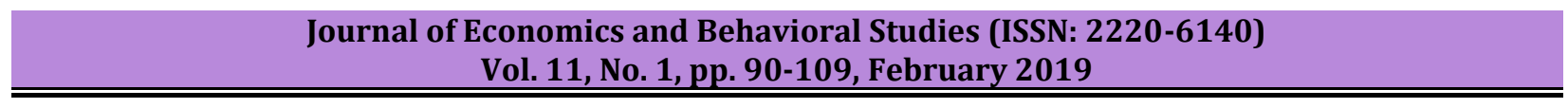

C). is a strategic data because it is a measure of the Government's performance (especially the Indonesian case).

The Role Of Fiscal Policy In Reducing Welfare Gap: As known that fiscal policy can include income, expenditure, financing, and others. Because this study focuses on discussing the welfare of the population / region and is also closely related to the discussion of poverty, the most suitable fiscal policy to prioritize is related to the state expenditure policy. With this concept, there is a narrowing of meaning because poverty is only seen as an economic inability to meet basic food and non-food needs.

Prasetya (2012) in Aziz (2016): Said that in macroeconomic theory, state expenditure consists of three main elements that can be categorized as follows:

- State expenditures on employee salaries and changes that have an effect on macroeconomic conditions because changes in government employee salaries will affect the level of public demand for goods and services indirectly.

- State expenditures for routine purchases of goods and services by the government.

- State expenditures in the form of direct gifts to citizens such as payment of subsidies or direct assistance to various groups of people, interest payments for government loans to the public, pension payments, and others. According to the author, financial transfers to the regions in the form of balancing fund policies also fall into this category. The government can also direct state expenditures for certain purposes that have been set before. That mean, if the government wants to focus on resolving the welfare gap between people and regions in Indonesia then this can be pursued by allocating the priority expenditure of the state to implement programs / activities that have the aim to reduce the welfare gap.

Wildavsky (2003) in Aziz (2016): Argued that the control of state expenditure included the following points:

- Controlling state expenditure is when the public needs a program but on the other hand the government cannot suppress overall state spending which is also important and on the other hand, the source of national income is very limited.

- Controlling state expenditure is when the government approves certain types of expenditure but needs to choose and prioritize which types of spending are the broadest choice of the community and which are the limited choices of citizens.

- Reducing or increasing state expenditure is the absolute right of the government the government does not require recommendations from any party in managing its spending, especially when in nonemergency conditions.

Busatto (2011) in Aziz (2016): which explains that public expenditure is generally a tool used by the state to influence the living conditions of its citizens directly. Examples of state expenditures are school construction, teacher salaries, and provision of school books that seek to improve population education, payment of doctors' honorariums, construction of hospitals, or actions to improve the health of the population and others.

\section{Results and Discussion}

The Indonesian state faces a number of crucial problems in order to realize economic prosperity for its people. The fundamental problem that must be faced is the occurrence of a welfare gap between residents and regions in Indonesia. The most relevant measure of the welfare gap is by knowing poverty indicators and other indicators such as the condition of education and health of a population in a particular area.

Poverty in Indonesia: The annual development of the Indonesian population can be seen in table 2 below. 
Table 2: Number of Poor Population, Percentage of Poor Population and Poverty Line, 2010-2017

\begin{tabular}{llllllllll}
\hline Year & \multicolumn{2}{l}{$\begin{array}{l}\text { Number } \\
\text { (Million)) }\end{array}$} & Poor & People & \multicolumn{2}{c}{ Percentage of Poor People } & \multicolumn{2}{c}{$\begin{array}{c}\text { Poverty } \\
\text { (RP/capita/Month) }\end{array}$} \\
& City & Village & City + Village & City & Village & City + Village & Kota & Desa \\
\hline 2010 & 11.10 & 19.93 & 31.02 & 9.87 & 16.56 & 13.33 & 232,989 & 192,354 \\
Mar 2011 & 11.05 & 18.97 & 30.02 & 9.23 & 15.72 & 12.49 & 253,016 & 213,395 \\
Sept 2011 & 10.95 & 18.94 & 29.89 & 9.09 & 15.59 & 12.36 & 263,594 & 223,181 \\
Mar 2012 & 10.65 & 18.49 & 29.13 & 8.78 & 15.12 & 11.96 & 267,408 & 229,226 \\
Sept 2012 & 10.51 & 18.09 & 28.59 & 8.60 & 14.70 & 11.66 & 277,382 & 240,441 \\
Mar 2013 & 10.33 & 17.74 & 28.07 & 8.39 & 14.32 & 11.37 & 289,042 & 253,273 \\
Sept 2013 & 10.63 & 17.92 & 28.55 & 8.52 & 14.42 & 11.47 & 308,826 & 275,779 \\
Mar 2014 & 10.51 & 17.77 & 28.28 & 8.34 & 14.17 & 11.25 & 318,514 & 286,097 \\
Sept 2014 & 10.36 & 17.37 & 27.73 & 8.16 & 13.76 & 10.96 & 326,853 & 296,681 \\
Mar 2015 & 10.65 & 17.94 & 28.59 & 8.29 & 14.21 & 11.22 & 342,541 & 317,881 \\
Sept 2015 & 10.62 & 17.89 & 28.51 & 8.22 & 14.09 & 11.13 & 356,378 & 333,034 \\
Mar 2016 & 10.34 & 17.67 & 28.01 & 7.79 & 14.11 & 10.86 & 364,527 & 343,647 \\
Sept 2016 & 10.49 & 17.28 & 27.76 & 7.73 & 13.96 & 10.70 & 372,114 & 350,420 \\
Mar 2017 & 10.67 & 17.10 & 27.77 & 7.72 & 13.93 & 10.64 & 385,621 & 361,496 \\
\hline
\end{tabular}

Source: LKPP, 2017 (May 2018), data edited

The data above shows that (1) the number of poor people in urban areas tends to be smaller than those in the village both in nominal and percentage terms, (2) the number of poor people continues to decline both in nominal and percentage terms and both in the village and in the city even though with a relatively small decrease, (3) the poverty line in the city is bigger than in the village, from time to time, and (4) the poverty line always experiences a nominal increase over time. Poverty will always occur as long as there is a gap in income distribution, according to Tumengkol (2012), poverty can be interpreted as a situation where a person is unable to choose himself according to the standard of living of the group and is also unable to utilize energy, mental, or physical in the group. And can also be interpreted as an economic gap or inequality in income distribution between high-income groups of people and low-income groups and the level of poverty or the number of people who are below the poverty line. Poverty that occurs above is also measured by a person's inability to fulfil his basic needs, both food and non-food, according to BPS (2017), BPS uses the concept of the ability to fulfill basic needs. With this approach, poverty is seen as an economic inability to meet basic food and non-food needs measured in terms of expenditure.

So the poor population is the population that has an average per capita expenditure below the poverty line. Similarly, it was concluded by Syawie (2011) that one of the concepts of poverty calculation applied in many countries, including Indonesia, is the concept of the ability to meet basic needs. The views related to the difficulty of poverty alleviation efforts are as described by Iryanti (2015) that since 2011, the decline in poverty rates has slowed down in absolute terms to decrease by less than 1 million poor people per year. This condition, according to Aryani, is caused by the condition of poverty that has now reached a stage that is already chronic and also because of macroeconomic conditions that have not been optimal. Disparities between provinces still occur with provincial poverty levels in Eastern Indonesia relatively higher than Western Indonesia. Therefore, the policy of reducing poverty in the future must pay attention to the following factors, such as (1) reducing economic inequality or inequality in income distribution between community groups, (2) meeting basic food and non-food needs, (3) conditioning macroeconomics to be more optimal and encourage economic growth; and (4) reduce disparity in poverty levels between provinces, namely in Eastern Indonesia and Western Indonesia.

Welfare Gap: One of the causes of poverty and also a problem in Indonesia is the problem of the welfare gap. This gap not only affects the economic but also psychological, health, and other aspects. Wide gaps result in 
various community weaknesses, such as unemployment, high crime, and other diseases. The following is a description of some indicators of welfare gap in Indonesia that focus on the provincial level as explained in the methodology section. The exposure of the data only to the provincial level allows the writer to analyze it more easily and also easier to compare between one/group of people or region with one/group of other people or other regions.

Poverty Depth Index: Graph 3 explains that there has been a gap in the average household expenditure in Indonesian society in 2015-2016, but the level of disparity in the DKI Jakarta province is relatively very low compared to the 2 years of observation while in Papua (2015) and in West Papua (2016) there is a very high level of inequality and above the average level of Indonesian household expenditure. So, there are serious problems in the different levels of depth of poverty and at the same time the level of welfare of this indicator, namely in the provinces of DKI (West Indonesia) and Papua / West Papua, especially in the 2 years of observation.

\section{Graph 3: 2015-2016 Poverty Depth Index by Province}

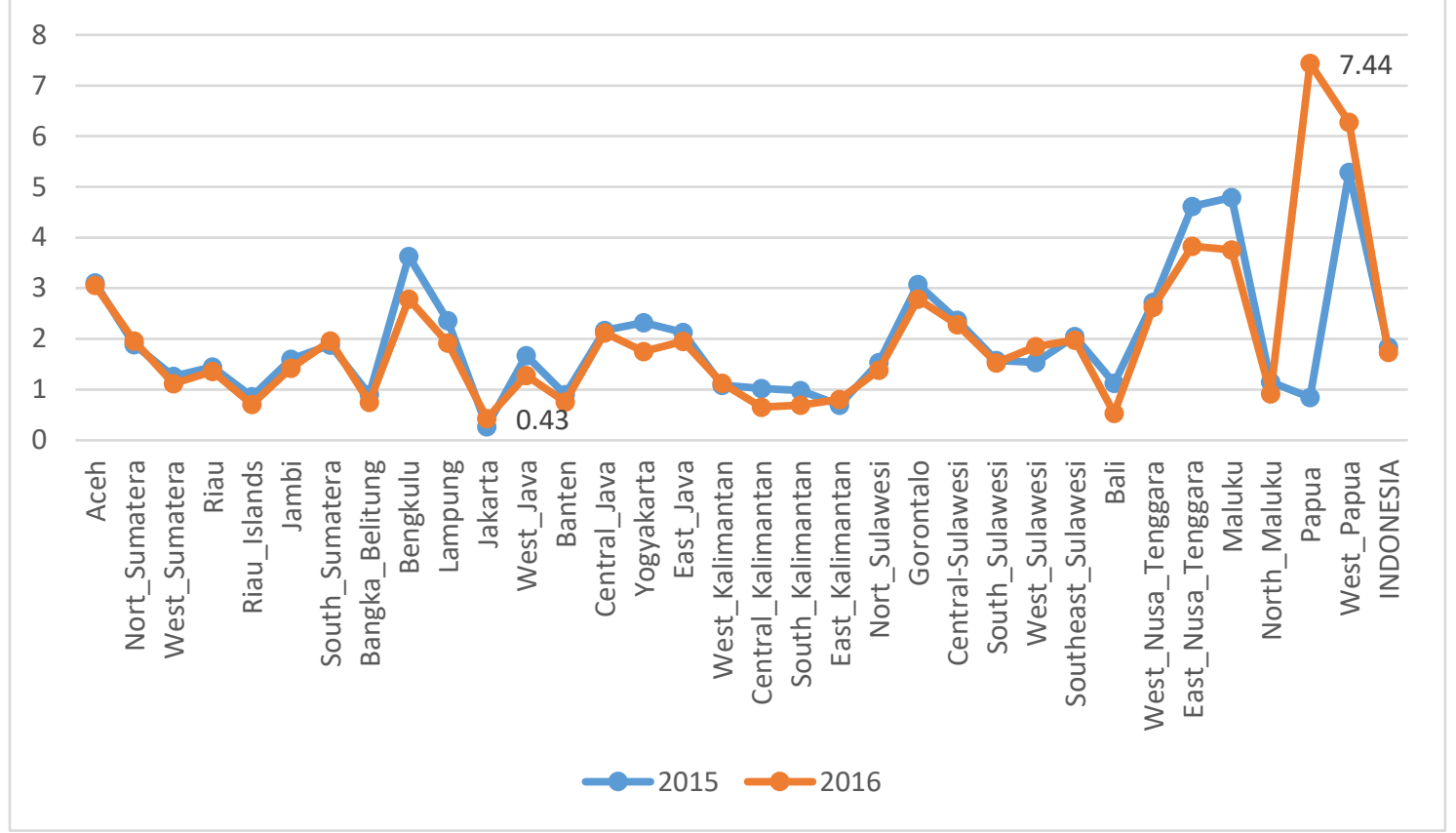

Source: BPS (2017), data edited

Data processing by the authors from BPS data (2017), shows that on average there are 5 provinces which tend to experience very good expenditure gaps (with a low index number) even below the national index, namely Jakarta, Bali, South Kalimantan, Riau Islands, and Central Kalimantan. And there are 5 provinces which on average tend to experience high expenditure gap indexes, namely Bengkulu, Aceh, Maluku, East Nusa Tenggara and Papua provinces, as shown in Graph 4 below. 
Graph 4: National Poverty Depth Index and 10 Lowest / Highest Provinces (Urban and Rural) in 2011-2016

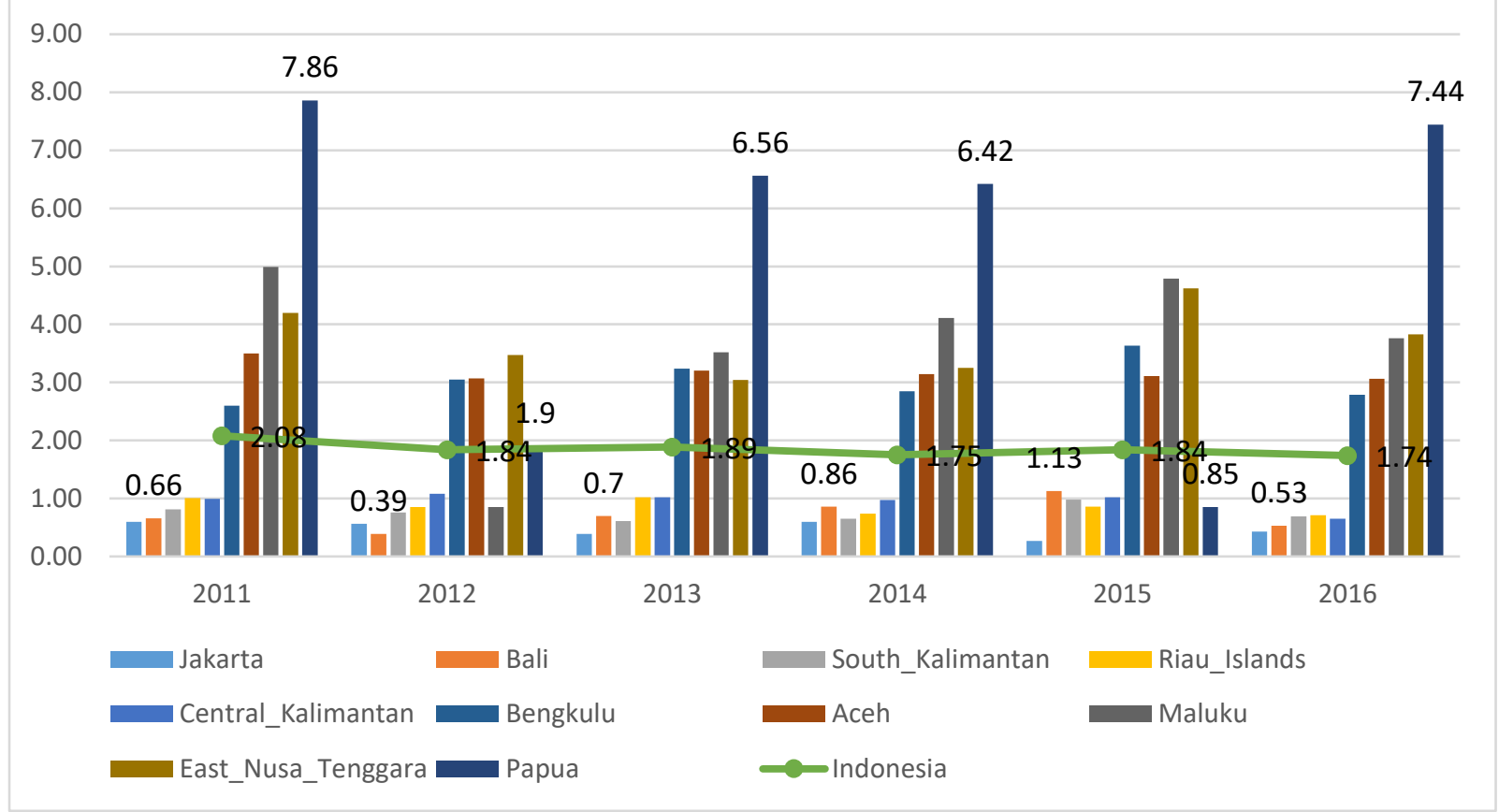

Source: BPS (2017), data edited

Poverty Severity Index: Graph 5 explains that there has been a gap in the distribution of household expenditures in Indonesian society in 2015-2016, but the level of inequality in Papua (2015) and Bali (2016) is relatively very low from these 2 years of observation while in West Papua (2015) and in Papua (2016) there is a very high level of inequality and above the level of distribution of Indonesian household expenditure. So, on this indicator, there are also serious problems in the difference in the level of poverty severity and at the same time the level of welfare, especially in Bali (2016) and in Papua (2016).

\section{Graph 5: 2015-2016 Poverty Severity Index by Province}

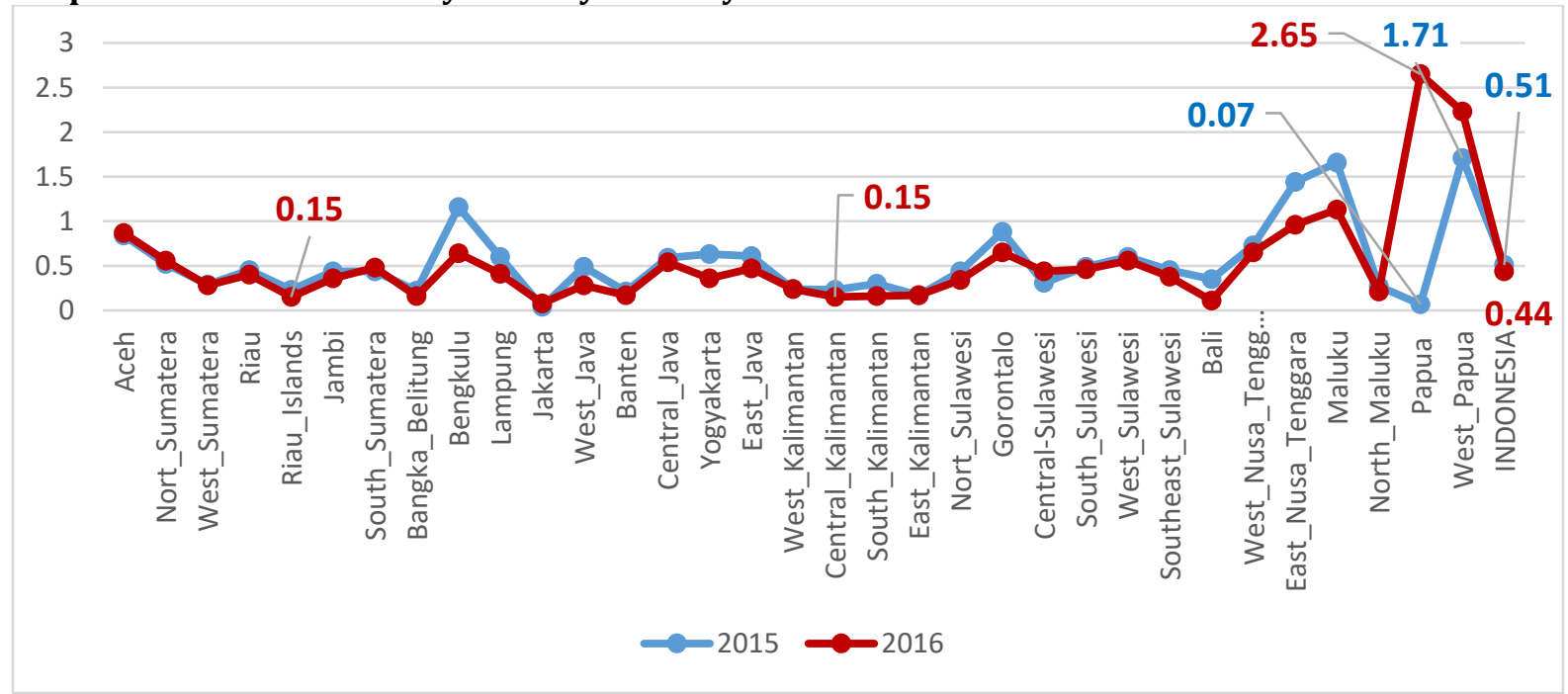

Source: BPS (2017), data edited

Based on data processing by the authors from BPS data (2017), it shows that there are 5 provinces that tend to experience disparities in the distribution of households that are able to make very good expenditures (with a 
low index number) even below the national index, namely DKI Jakarta province , Bali, Bangka Belitung, South Kalimantan, and North Maluku. And there are 5 provinces that tend to experience a high average expenditure gap index, namely the provinces of Aceh, NTT, North Maluku, West Papua and Papua, as shown in graph 6 below.

Graph 6: National Poverty Severity Index and 10 Lowest / Highest Provinces (Urban and Rural) in 20112016

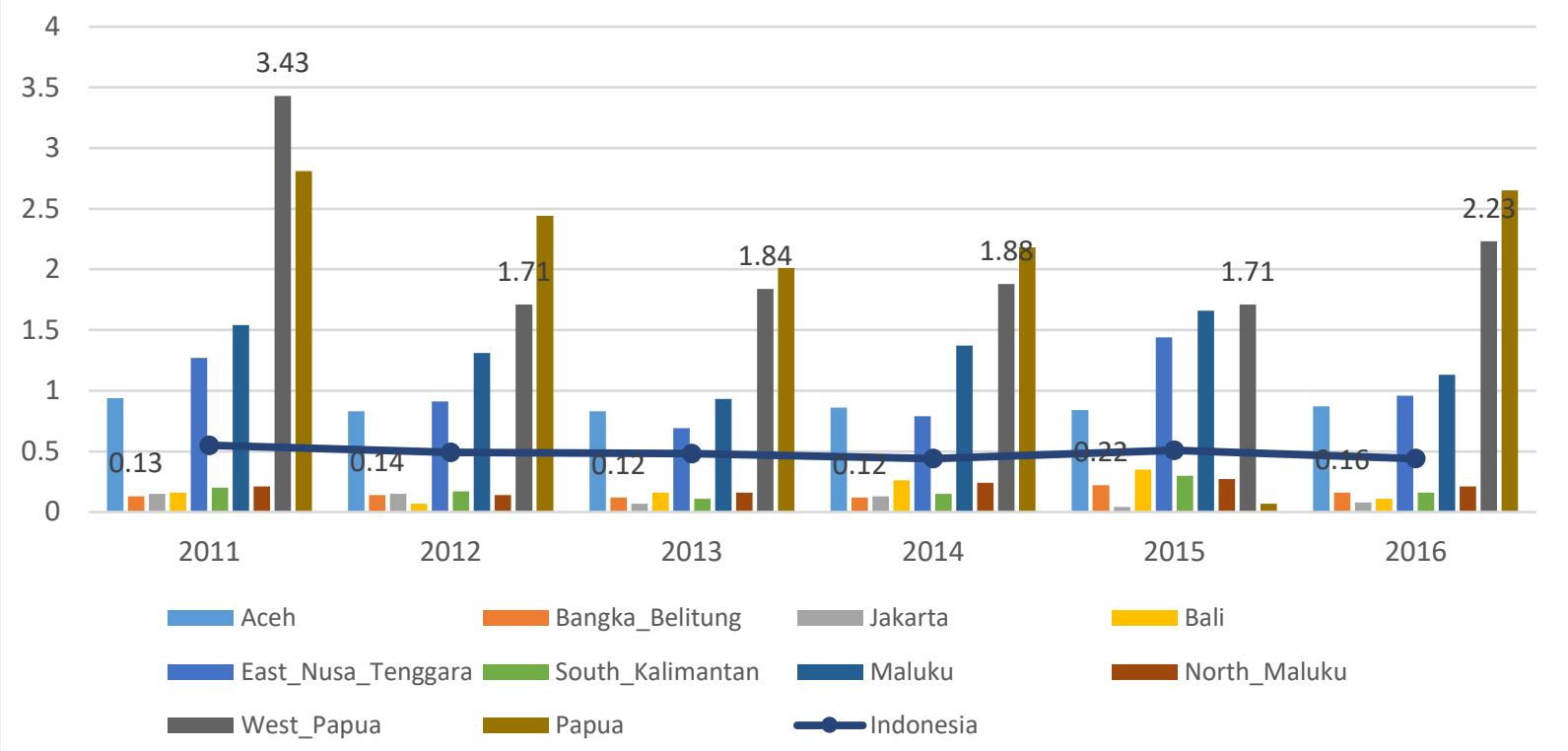

Source: BPS (2017), data edited

Gini Coefficient Index: From graph 7 above it can be explained that there has been a severe inequality in the income of Indonesian people both nationally and per province except certain provinces in certain years such as Bangka Belitung province (Babel) which has a fairly low level of income inequality and under other territories.

\section{Graph 7: 2015-2016 Provincial Gini Coefficient of Indexes}

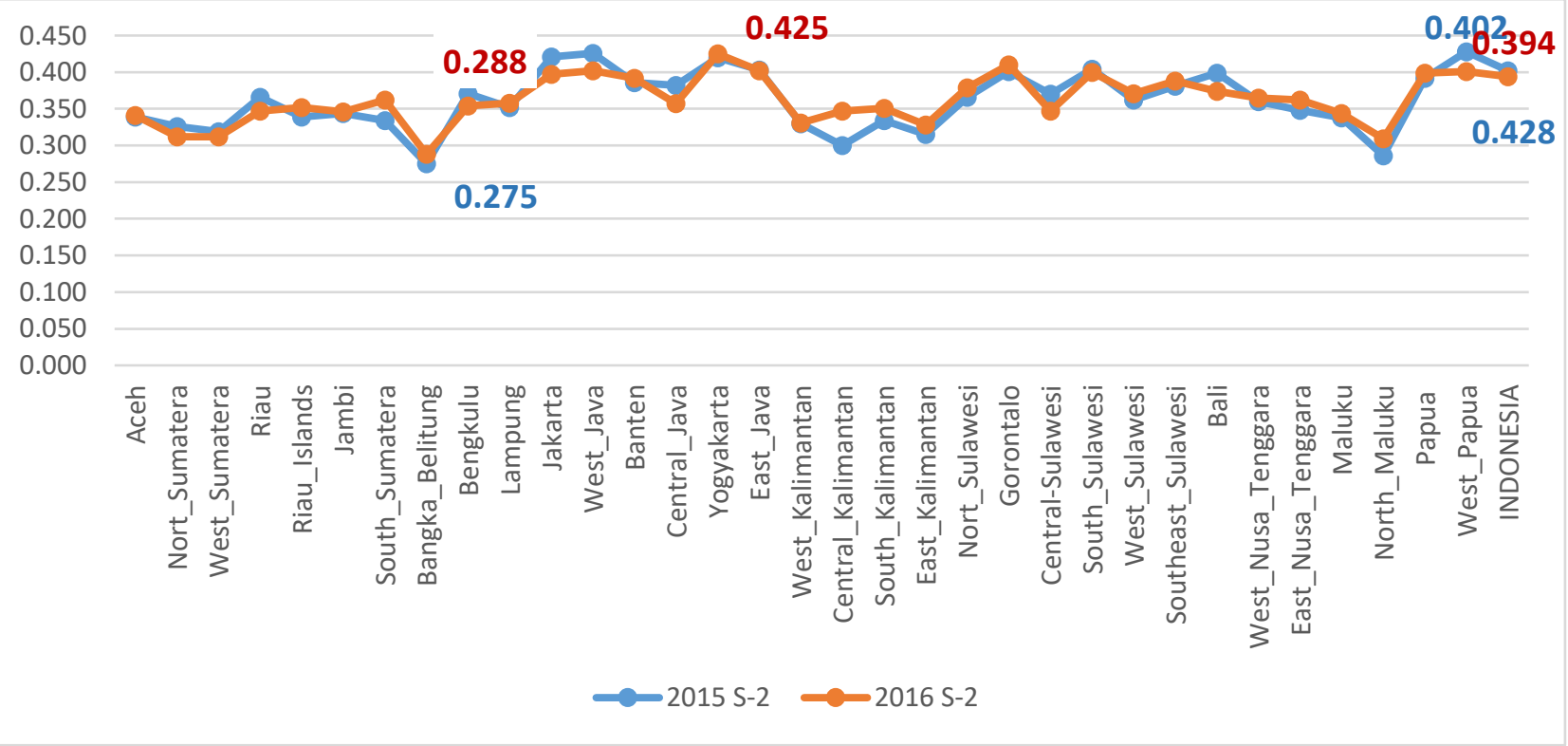

Source: BPS (2017), data edited 
The results of data processing by the authors from BPS data (2017) in graph 8 show that there are 5 provinces that tend to experience severe inequality in the community's income on average (during 6 years of observation) which is the province of Yogyakarta, South Sulawesi, Gorontalo, Papua and Jakarta even at the national level. The Gini Coefficient Index of Indonesia is also at a level of inequality in fairly poor income. While the other 5 provinces have a fairly low Gini coefficient index, this means that the 5 provinces have an average level of good income distribution, the five provinces are Central Kalimantan, West Sumatra, North Sumatra, North Maluku, and Bangka Belitung.

Graph 8: National Gini Ratio \& 10 Provinces with Highest / Lowest Gini Ratio and Range in the Average Period 2011-13 to 2014-16

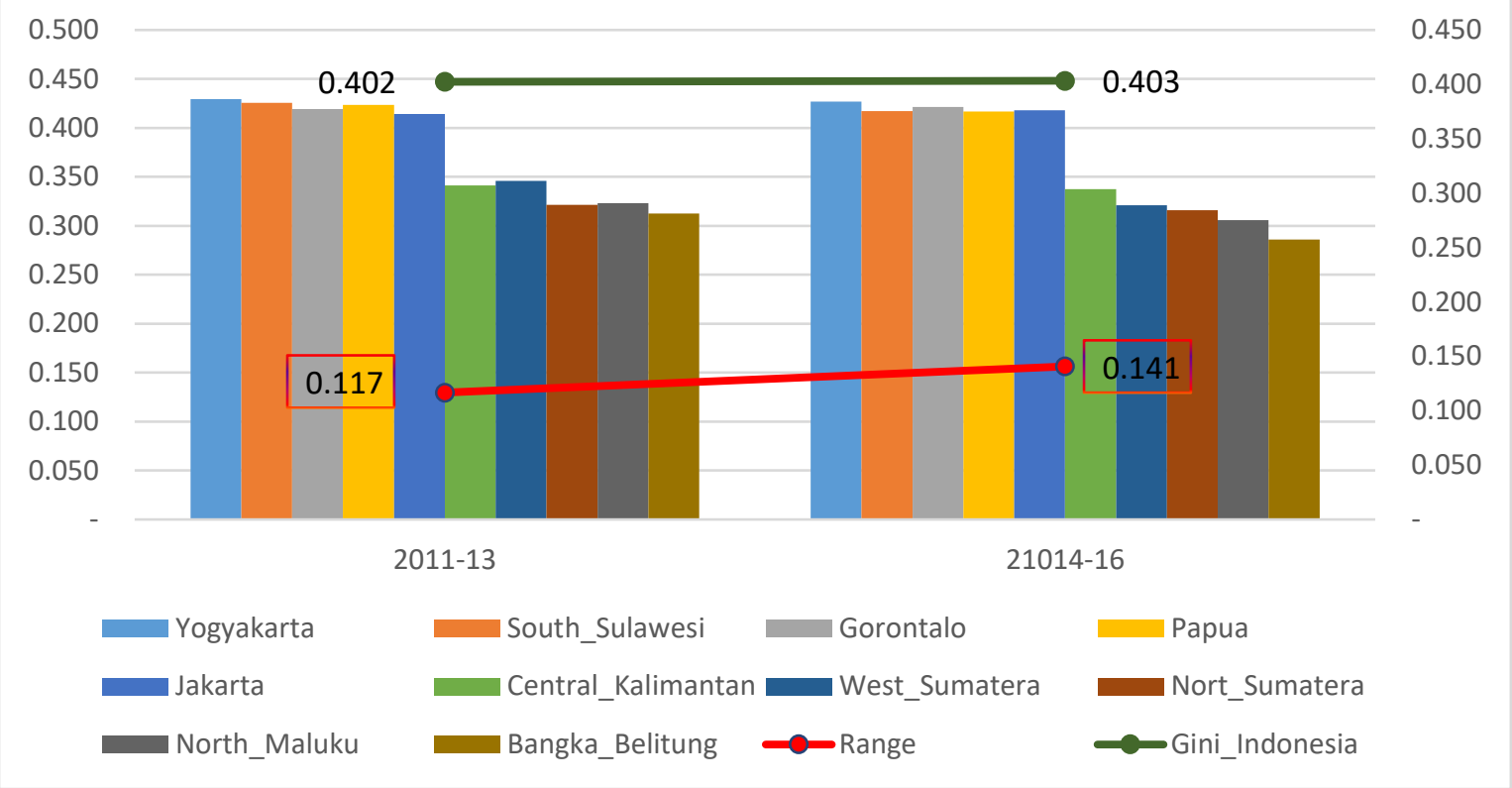

Source: BPS (2017), data edited

And based on the processing of data on graph 9, it can be explained that if calculated by the standard deviation formula the inequality between provinces shows a fairly low number, this means that generally, all provinces in Indonesia tend to experience a level of inequality in the income of people who are in almost the same condition. However, in the provincial average, there is a far difference with the index at the national level.

\section{Graph 9: National Gini Ratio in Average, Range, Deviation Standard for Period 2011-2016}

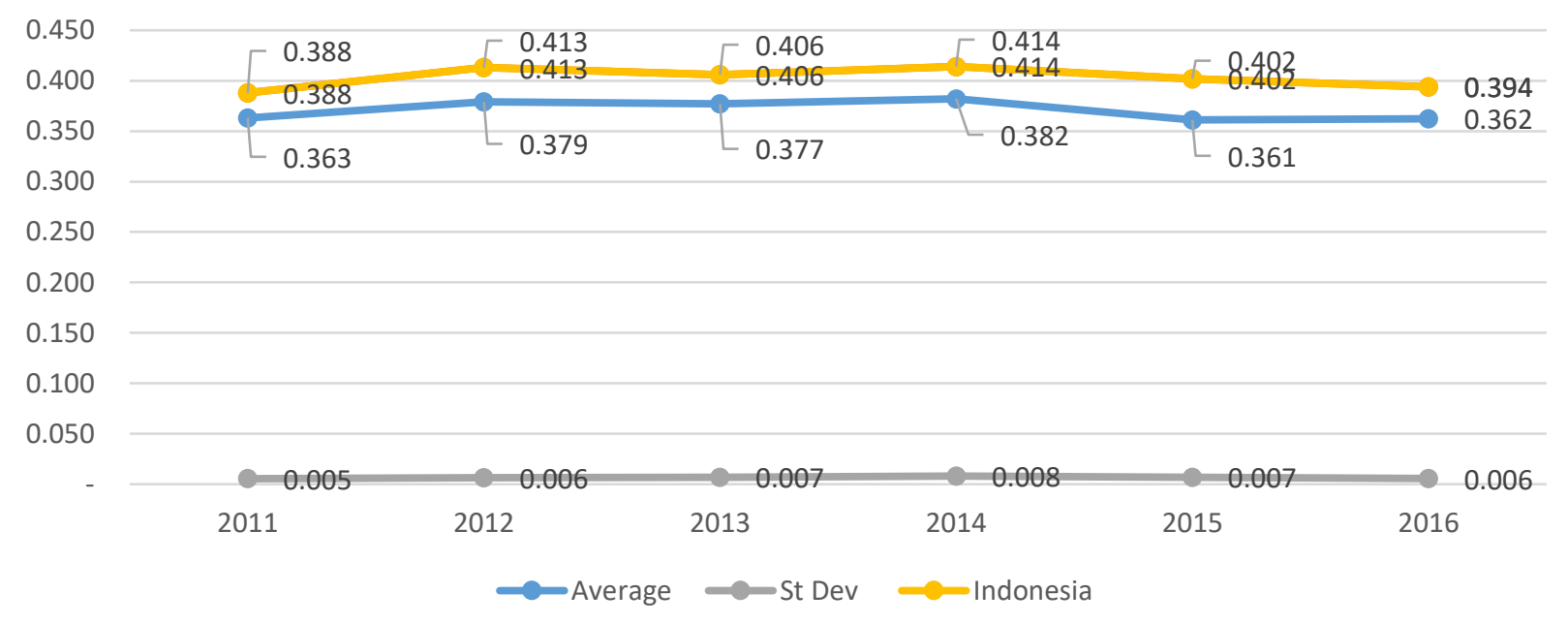

Source: BPS (2017), data edited 
In graph 10 it can be explained that DKI Jakarta province has the highest level of human development success in these 2 years of observation even exceeding the National HDI. On the contrary, Papua Province has the lowest HDI figure from all provinces in the 2 years. This again proves that in general the provinces in the western part of Indonesia have relatively better human development conditions and levels of welfare. When viewed from the HDI condition in graph 10 below, it can be concluded that in these two years of observation there was no significant shift / change in human development from the three elements of the HDI, this is evidenced from the position of the HDI number that barely changes in all provinces.

Graph 10: 2015-2016 Provincial Human Development Index per Province

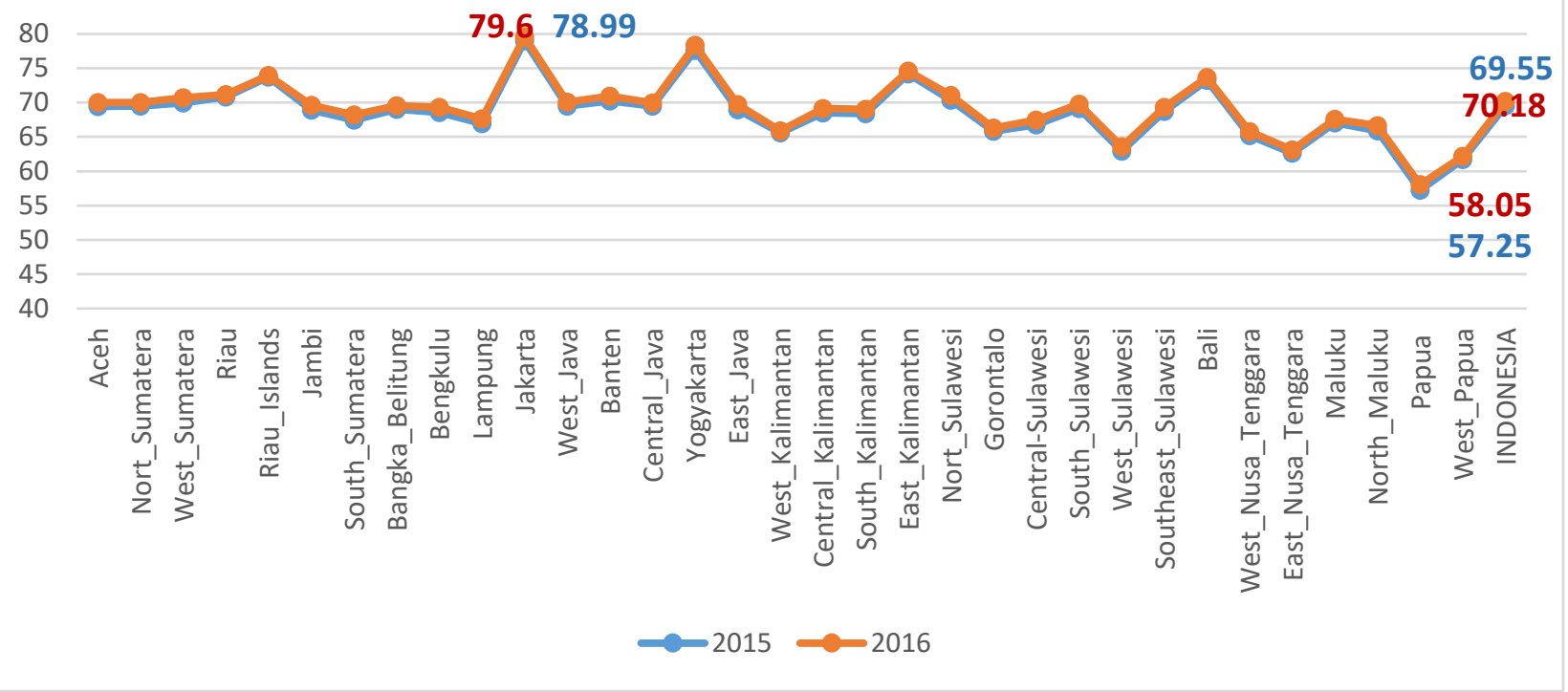

Source: BPS (2017), data edited

The results of data processing by the authors from BPS data (2017) on graph 11 show that there are 5 provinces that tend to experience a good process of human development (during 6 years of observation), namely DKI Jakarta, DIY, East Kalimantan, Riau Islands, and Bali. The average number of HDI from the 5 provinces even exceeds the average national HDI figure, while the 5 provinces with low HDI scores are West Kalimantan, West Sulawesi, East Nusa Tenggara, West Papua, and Papua.

Graph 11: National HDI and 10 Provinces with the Highest / Lowest HDI and Range in the Average Period 2011-2013 and 2014-2016

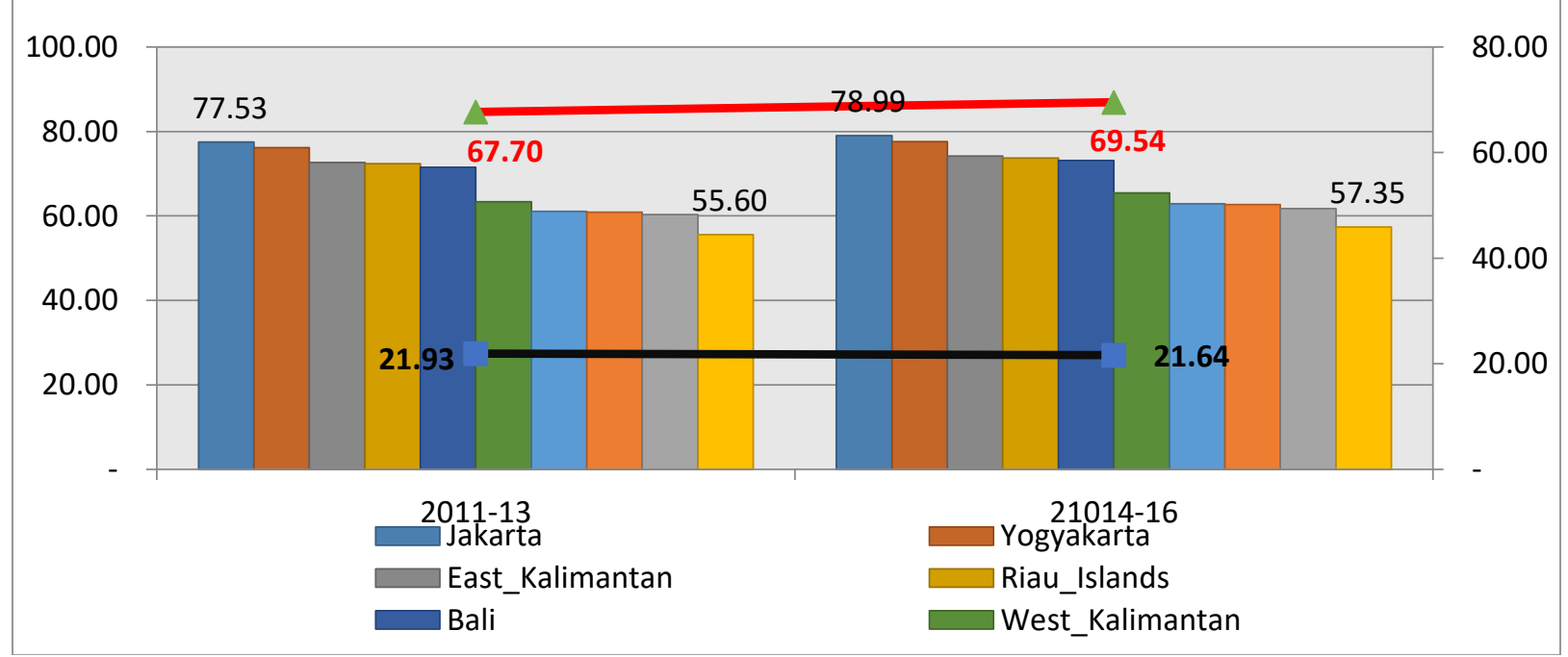

Source: BPS (2017), data edited 
However, in general, in the years of observation in all regions or groups of regions in Indonesia, it has been pointed out that there is a prosperity gap of the 4 indicators used although with different levels of inequality. Indirectly, this condition shows that the development in Indonesia is not evenly felt by all Indon esian people proportionally, this can occur due to several factors such as the different conditions of natural resources and human resources, government management in each region, economic development in a general sense (such as the production and investment side), fiscal capacity between regions, central government policies for each region, and others that may indicate different conditions and levels in each region (province).

Graph 12: National HDI and HDI 33 Provinces in Average, Range, Standard Deviation, Periode 20112016

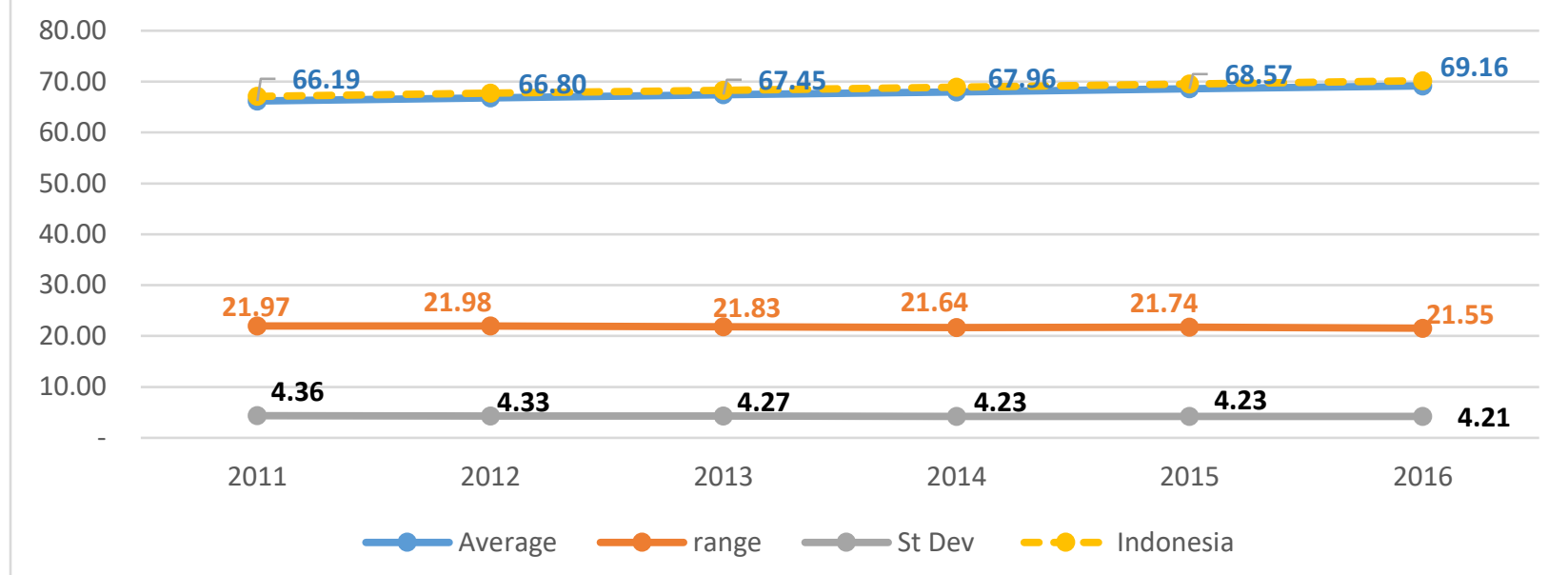

Source: BPS (2017), data edited

According to Faisal, (2011) in Siswanto, (2012) several things that cause differences that cause gaps (in each indicator), including

- Differences in the characteristics of the abundance of natural resources.

- Demographic differences.

- Differences in human resource capabilities.

- Differences in potential locations.

- Differences in aspects of accessibility and power in decision making.

- Differences in aspects of market potential.

While the factors causing the occurrence of the economic gap between provinces or regions in Indonesia according to Faisal: 2011 in Siswanto: 2012, among others are:

- Concentration of regional economic activities.

- Investment allocation.

- Low level of factor production mobility between regions.

- Differences in natural resources between provinces.

- Economic development in natural resource-rich areas will be more advanced and prosperous communities compared to areas that are resource-poor.

- Differences in demographic conditions between regions.

- Lack of trade between provinces.

Graph 13 below shows the proportion of state expenditure on an annual basis both managed directly by the central government and in the form of Funds Transfer to Local Governments. The graph illustrates an increase in the realization of state expenditure from 2012 - 2017. 


\section{Graph 13: Development of Realization of State Expenditures FY 2012 - 2017 (IDR Trillion)}

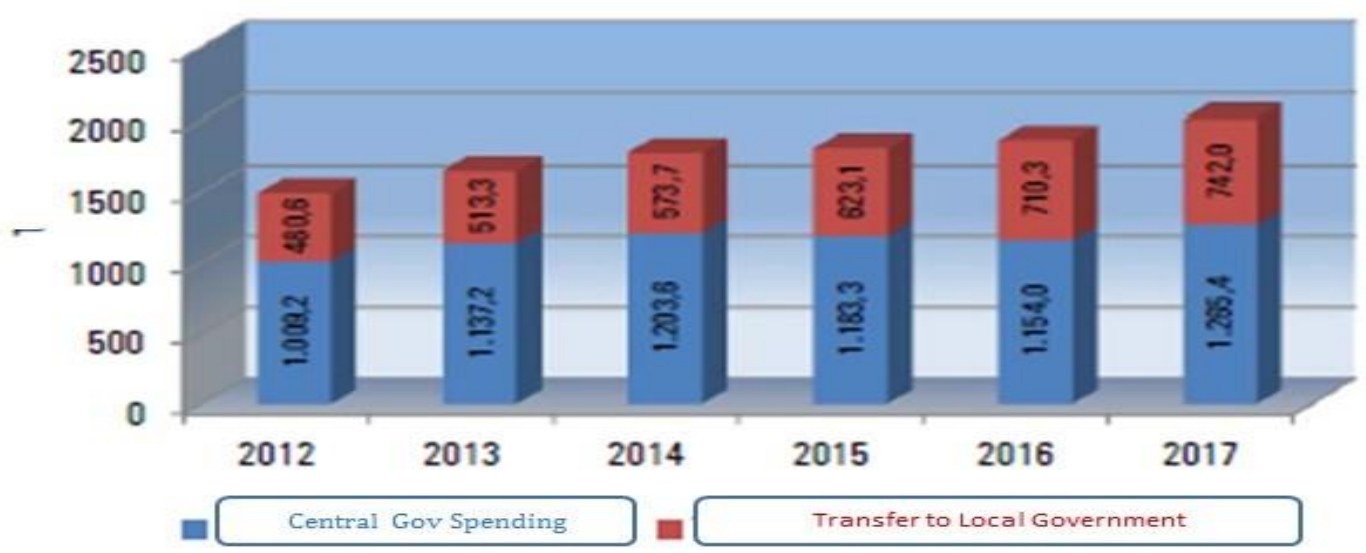

Source: LKPP, 2017 (May 2018), data edited

In terms of spending, central government spending remains focused on efforts to fund national priority programs in the form of infrastructure development and reducing inequality and poverty.

Application of Fiscal Policy: At the level of implementation, the government has actually allocated APBN budget/expenditure which aims to increase the level of people's welfare both directly and indirectly through various programs and activities in the fields of education, health, infrastructure development for basic services, and spending to reduce poverty in Indonesia. In general, the flow of utilization of APBN expenditure (whether through central government spending or in the form of Funds Transfer to Local Governments) for programs / activities related to the welfare indicators of the people is as shown in Figure 1 below.

\section{Figure 1: Policy on State Budget Expenditure Allocation Welfare Indicators}

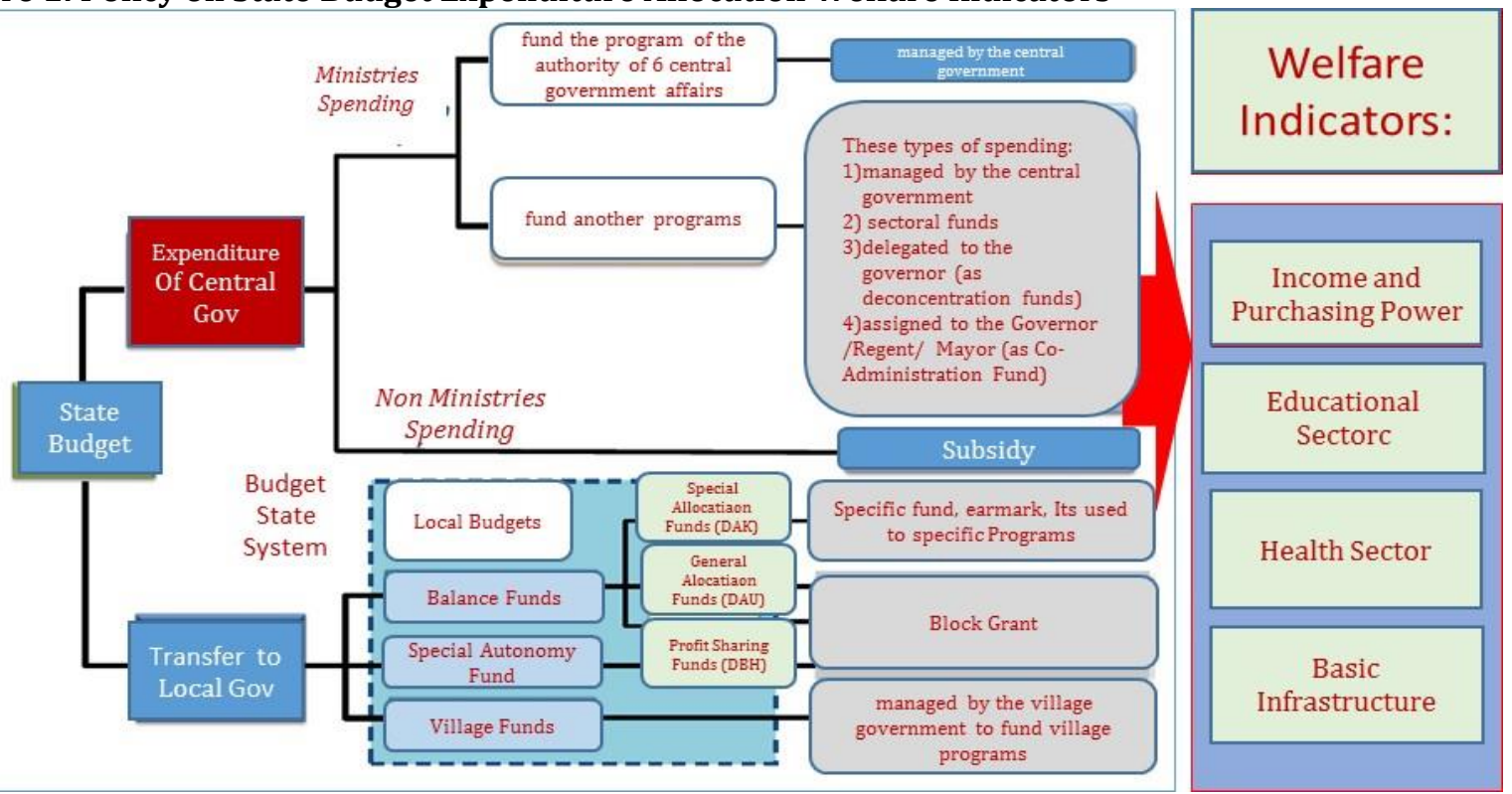

Source: Illustration of the author, TNP2K (2016), data edited

From Figure 1 above, it can be seen that in general the APBN expenditure is divided into 2 major posts, namely, expenditures managed directly by the Central Government and expenditures in the form of Funds Transfer to Local Governments allocated to 34 provinces, 542 districts and cities as well as 74,754 villages. Among these expenditures, there are several types of APBN expenditures in each fiscal year that specifically enter into the four types of programs / activities in order to improve the welfare of the people, both directly and indirectly. 
Table 3: Realization of Central Government Expenditures by 2017 Function (IDR Billion)

\begin{tabular}{|c|c|c|c|c|}
\hline Code & Function & Budgetc & FY 2017 & $\%$ \\
\hline 1 & Public service & $362.640,5$ & $307.147,2$ & $84,70 \%$ \\
\hline 2 & Defensec & $115.038,9$ & $117.506,6$ & $102,15 \%$ \\
\hline 3 & Public order and Security & $145.469,6$ & $135.748,1$ & $93,32 \%$ \\
\hline 4 & Economy & $327.079,7$ & $307.787,5$ & $94,10 \%$ \\
\hline 5 & Environment & $12.562,9$ & $10.613,7$ & $84,49 \%$ \\
\hline 6 & Housing and Public Facities & $30.074,1$ & $27.277,4$ & $90,70 \%$ \\
\hline 7 & Health & $58.728,2$ & $57.225,1$ & $97,44 \%$ \\
\hline 8 & Tourisme and Culture . - & $6.457,5$ & $5.770,6$ & $89,36 \%$ \\
\hline 9 & Religion & $9.786,4$ & $8.870,4$ & $90,64 \%$ \\
\hline 10 & Education & $143.997,6$ & $138.507,3$ & $96,19 \%$ \\
\hline \multirow[t]{2}{*}{11} & Population dan Social Protection & $155.121,3$ & $148.905,5$ & $95,99 \%$ \\
\hline & Total & $1.366 .956,6$ & $1.265 .359,4$ & $\mathbf{9 2 , 5 7 \%}$ \\
\hline
\end{tabular}

Source: LKPP, 2017 (May 2018), data edited

Table 3 shows that the realization of central government spending on functions including improving welfare such as housing and public facilities, health and social protection reached more than Rp.370 trillion. In LKPP, MoF (2017) explained that in order to solve the welfare gap problem, the implementation of fiscal policy in the form of state expenditure allocation can be carried out on two dimensions of development which are the government's priorities, namely:

A. Dimensions of Equitable and Regional Development. One of the national priority agendas is to improve income distribution so that the bottom 40 percent of the population's income can grow much better so as to create a better quality of life. Through this priority, the improvement of the quality of life is pursued through equal distribution between income groups, and the reduction of inter-regional development disparities.

B. Leading Sector Development Dimensions, aimed at increasing people's productivity and competitiveness in international markets; and realize economic independence by moving the strategic sectors of the domestic economy. Priority development priorities for the sector include food sovereignty, maritime and maritime affairs, energy sovereignty, tourism development, as well as accelerating industrial growth and Special Economic Zones (SEZs). Furthermore, to achieve this development focus, the utilization of central government spending is directed at improving the quality of productive spending and priorities as explicitly contained in LKPP, MoF (2017), which among others is focused on:

- Increase the efficiency and sharpening of non-operational spending to increase fiscal space so that the efficiency of spending can be diverted to priority spending to finance programs to reduce poverty and economic disparities between populations and regions.

- Increasing productive spendings such as the construction of electricity facilities and infrastructure, connectivity between regions, housing, sanitation and clean water. This is important to facilitate the flow of goods and services between regions and can reduce the cost of living so as to improve the welfare of life.

- Strengthening the implementation of priority programs in the fields of health, education, energy and food sovereignty, marine and maritime affairs, and industry and tourism.

- Increasing the effectiveness and quality of social protection programs in all fields such as health and education.

- Distributing non-cash social assistance programs and subsidies that are more targeted so that the effectiveness of the program can be achieved well.

Graph 14 also shows that the nominal balance fund figure on average refers to the number of realization that continues to rise in each province, even though the range between the highest and lowest daper recipients is also higher which shows that there is a potential to cause social inequality economy between regions. 


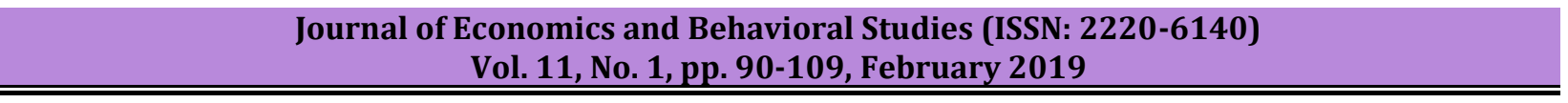

Graph 14: 33 Provinces in Average, Range, Standard Deviation Period 2011-2016 (IDR Trillion)

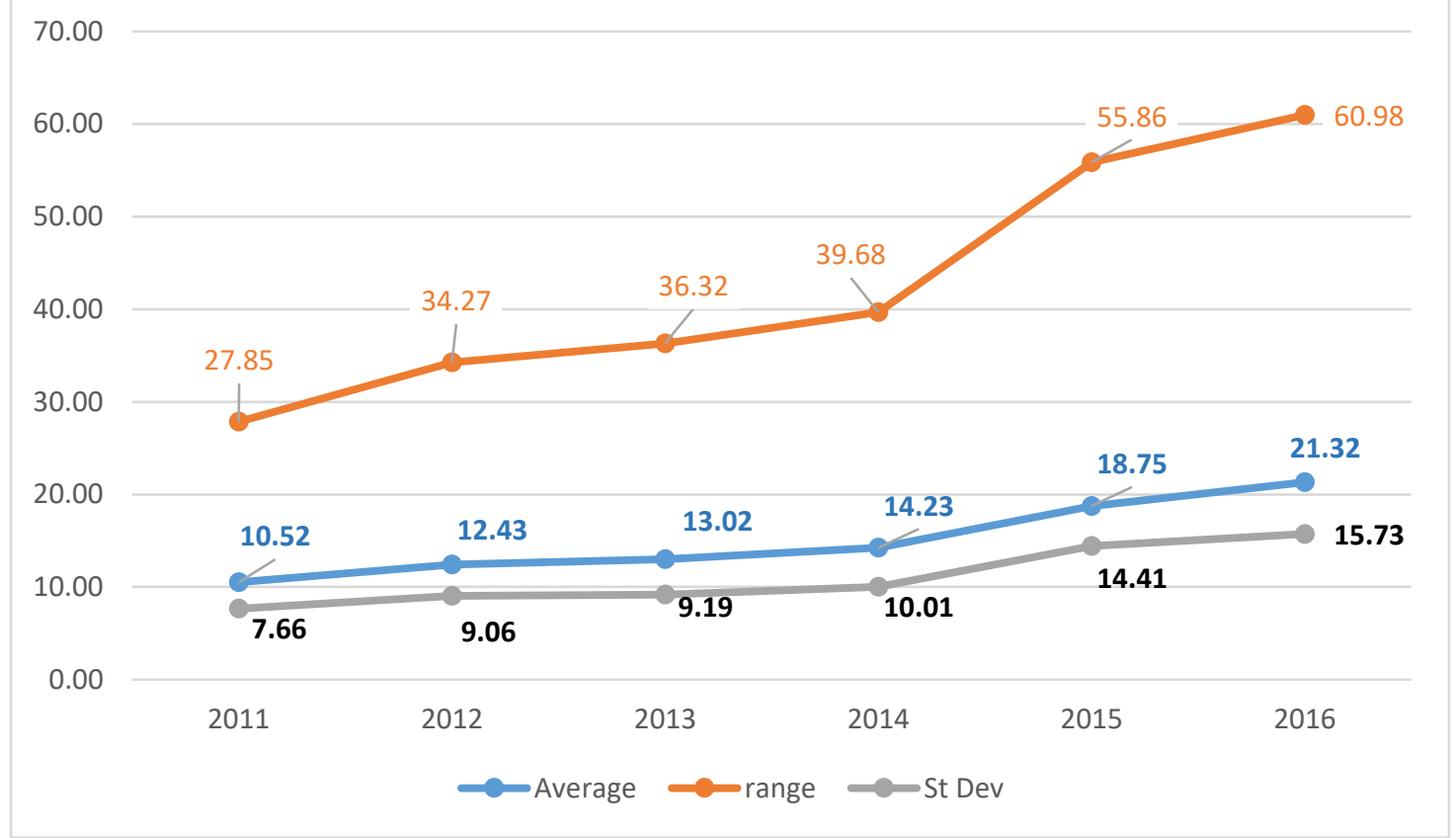

Source: LKPP, 2017 (May 2018), data edited

Sometimes there is a difference between planning (in this case the allocation of APBN expenditures) made by the Government as a policy maker and the output produced and expected, for example, is whether the allocation and realization of functional APBN expenditures can improve welfare and reduce poverty. Suryono (2014) has warned that the policy problem or often called the implementation gap is a condition in the policy process that is always open to the possibility of differences between what is planned by the policymaker compared to the results / achievements achieved from the implementation of the policy. In realizing a product of public policy (such as APBN expenditure allocation policy) which has the nuances of people's welfare, the problem lies not only in the national political will but also in the implementation of the actions of the national political will. Therefore, the APBN expenditure allocation policy must pay attention to many factors such as: calculating the level of effectiveness, determining the scale of priority spending, maintaining spending efficiency, and improving the quality of state spending. As in previous budget years, the Government has also channelled Fund Transfers to Regional Governments in 2017 amounting to 741.99 trillion (+ 25 percent of total expenditure on the APBN). The details are as shown in graph 15 below. 
Graph 15: Realization of Funds Transfer to the Accumulated Regional Government of 2017 Province (IDR Trillion)

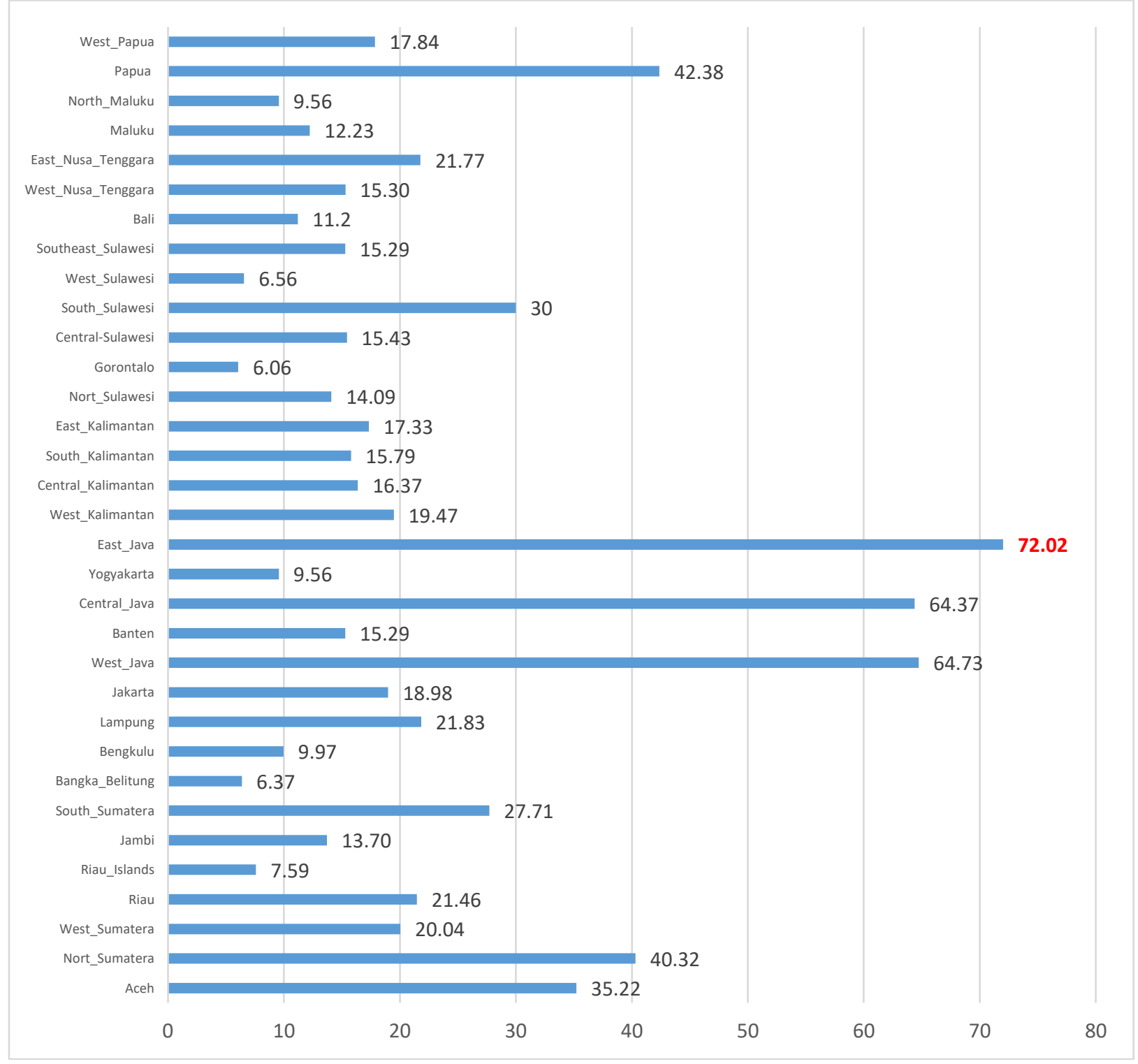

Source: LKPP, 2017 (May 2018), data edited

Fund transfers to the Regional Government for the majority are in the form of block grants that can be used by each regional government to carry out development in all fields, especially in order to reduce poverty and improve the welfare of their respective people which in turn is for all Indonesian people. Fund transfers to local governments are directed to strengthen funding for regional and rural development in order to accelerate the realization of public welfare, reduce the gap in public services between regions and support the achievement of national priorities. While the 5 largest provinces receiving Funds Transfer to Regional Governments are still dominated by provinces in Java and vice versa, the provinces receiving the smallest balance funds tend to be in Eastern Indonesia as explained by graph 16 below. Is this condition also a factor in the occurrence of disparities between regions. 


\section{Graph 16: 10 Provinces with the High est / Lowest Balance Balancing Funds and Range in the Average} Period 2011-13 to 2014-16 (IDR T)

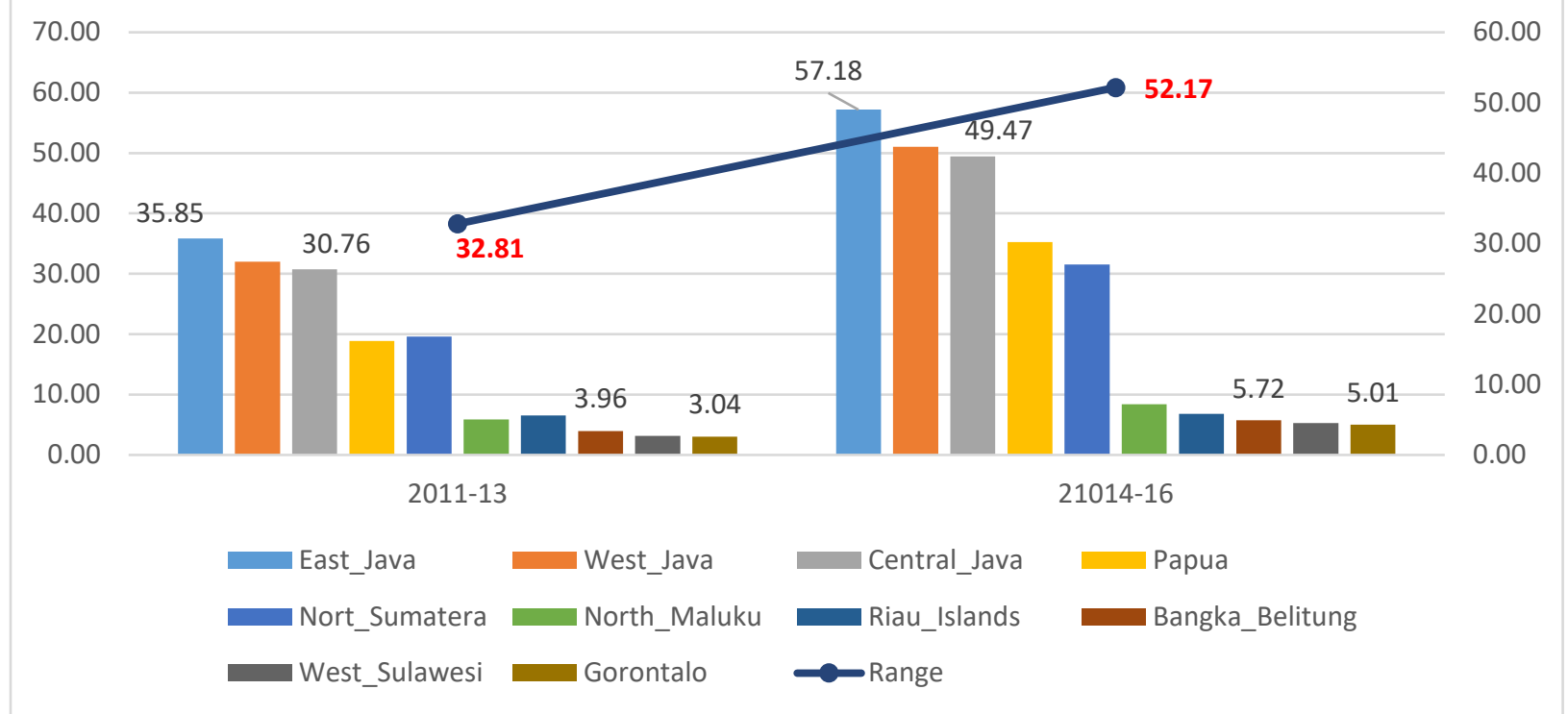

Source: LKPP, 2017 (May 2018), data edited

So, actually, the government's efforts to prosper the people through the APBN expenditure allocation policy are already quite optimal because in addition to the realization of direct expenditure from the Central Government there are also some expenditure allocations which are Fund Transfers to Local Governments in the scheme of fiscal decentralization and regional autonomy. According to Sasana (2009), the implementation of fiscal decentralization has been carried out since January 1, 2001. Through regional autonomy and fiscal decentralization, local governments have the authority to explore revenues and carry out the role of allocation independently in establishing development priorities. Autonomy and fiscal decentralization can better equalize development in accordance with the wishes of the regions to develop regions according to their respective potential. However, in its efforts to resolve the welfare gap through this state expenditure allocation, the Government must also pay attention to its fiscal capacity and sustainability so that the State Budget does not face excessive financing pressure (Nurcholis: 2012 in Aziz: 2013) and fiscal sustainability is also related to efforts to remain maintain the level of fiscal fisability (Haryo Kuncoro, 2011 in Aziz: 2013). Therefore, paying attention to the importance of maintaining capacity, sustainability and fiscal solvency, the government must pay attention to effective, efficient and quality state expenditure, paying attention to the priority expenditure scale so that the government's fiscal policy objectives to reduce the welfare gap between residents and regions can be achieved well and The State Budget remains in good health.

\section{Conclusion and Recommendations}

There are various indicators that develop in Indonesia to measure the level of inequality in Indonesia such as the Poverty Depth Index, Poverty Depth Index, and Gini Coefficient Index. And there are also indicators used to measure development and the level of welfare in Indonesia, namely the HDI. Fiscal policy through the allocation of spending on the National Budget (both managed directly by the Central Government and through the Fund Transfer mechanism to the Regional Government) is expected to be one solution in solving the welfare gap between residents and regions that occur in Indonesia. So, the government actually has made an effort to solve the gap problem through the allocation of state expenditures that are quite large and tend to always increase. Other efforts are also made through the creation of development programs and activities that are expected to solve the gap. However, in its efforts to resolve the welfare gap through this state expenditure allocation, the Government continues to pay attention to its fiscal capacity, sustainability and solvency so that the APBN remains in good health. 


\section{Recommendations}

- The government is expected to be able to determine the most accurate indicators of the welfare gap between residents and regions in the future so that it can describe the actual inequality conditions with a high level of precision so that the policy to be taken is expected to be appropriate;

- The decision to allocate expenditure on the state budget in order to alleviate the welfare gap must pay attention to state spending that is more effective, efficient, quality and prioritizes the priority scale so that it can solve the problem.

- The fiscal decentralization policy and the allocation of Funds Transfer to Regional Governments are expected to be more equal in development in accordance with the conditions, potential, and choices, the development model of each region.

- The central government should pay more attention to the allocation of Fund Transfers to Regional Governments located in Eastern Indonesia because besides those regions having weak resource potential, they usually do not have sufficient regional fiscal capacity, especially to implement development oriented programs / activities. reduction of the welfare gap.

- In its efforts to reduce the welfare gap, the Government must also pay attention to its fiscal capacity, sustainability and solvability so that the APBN does not face excessive financing pressure and the APBN remains in good health.

\section{References}

Aziz Abdul. (2013). Sustainable State Budget, Fiscal Risk Info, (1), 39-45.

Aziz Abdul. (2016). Maintaining Spending Effectiveness of Social Spending, Fiscal News IV edition 2016;

Andersen, J. G. (2012). Welfare State and Welfare State Theory, Working Paper, Centre for Comparative Welfare Studies, Department of Political Science, Aalborg University

The Central Bureau of Statistics / BPS. (2017), Social and Population Data, Economy and Trade, accessed online at https://www.bps.go.id/Subjek/view/id/ 23 \# subjectView Tab1 | accordion-list-subject1.

Bhatti., Arshad Ali., Naqvi., Hasnain, A. \& Batool, Zakia. (2018). Fiscal Policy and Its Role in Reducing Income Inequality: A CGE Analysis for Pakistan.

Busatto, Leonardo Maranhao. (2011). The Quality of Public Expenditure and its Influence on Economic Growth, The Institute of Brazilian Issues, The George Washington University.

Haryo Kuncoro. (2011). Indonesia's State Budget Sustainability and Its Implication for Financial System Stability, Romanian Journal of Fiscal Policy, (2), 1.

Iryanti, Rahma. (2015). Poverty and Inequality in Indonesia: Problems and Challenges, Deputy for Poverty, Employment, and SMEs.

Government of Indonesia Central Government Financial Statements (Audited LKPP). (2010-2017). Government of Indonesia.

Lustig, Nora. (2018). Fiscal Policy, Income Redistribution, and Poverty Reduction in Low- and Middle-Income Countries, CEQ Institute, Tulane University.

Nurcholis Madjid. (2012). Fiscal Policy and State Budget Preparation, Ministry of Finance's Financial Training and Education Agency.

Orosz, Agnes. (2017). Development of Welfare State Theory: A Review of the Literature, Magyar Közigazgatás, (2), 176-191.

Prasetya, Feri. (2012). Public Economy Module, Part V: Theory of Government Expenditure, Lecture Module Not Published, Brawijaya University Malang;

Roy, Rathin. \& Weeks, John. (2004). Making Fiscal Policy Work for the Poor, United Nations Development Programme (UNDP).

Sasana, Hadi. (2009). Analysis of the Impact of Economic Growth Gap between Regions and Absorbed Workers on Welfare in Districts / Cities in Central Java Province in the era of Fiscal Decentralization, Journal of Business and Economics (JBE), (16), 1.

Siswanto, Vely Kukinul. \& Santoso, Eko Budi. (2012). Determination of Regional Economic Gaps Based on the Urban Typology in Sidoarjo Regency, Journal of Pomits Engineering, 1(1), I-5.

Suryono, Agus. (2014). Public Policy for People's Welfare, Transparency (Scientific Journal of Administrative Sciences), (6), 2. 
Syawie, Mochamad. (2011). Poverty and Social Inequality, Journal of Information, (16), 3.

The Organization for Economic Co-operation and Development (OECD). (2015). OECD Economic Survey in Indonesia, OECD.

TNP2K. (2016). Improving the Effectiveness of the Budget of Ministries / Agencies To Reduce Inequality in Inter-Regional Welfare, Ministry of State Secretariat RI; EN

Tumengkol, Selvie, M. (2012). Social Problems As the Impact of Social Change and Its Solution Efforts (Case Study of Poverty Problems), Scientific Work, Social Sciences, Sam Ratulangi University Manado.

Wildavsky, Aaron. (2003). Controlling Public Expenditure: The Theory of Expenditure Limitation, OECD Journal on Budgeting, 2(4), 1608-7143. 